\title{
Jowonal
}

Cellular Neuroscience

\section{and 0 xidative Stress}

\author{
http://dergipark.gov.tr/jcnos
}

Former name; Cell Membranes and Free Radical Research
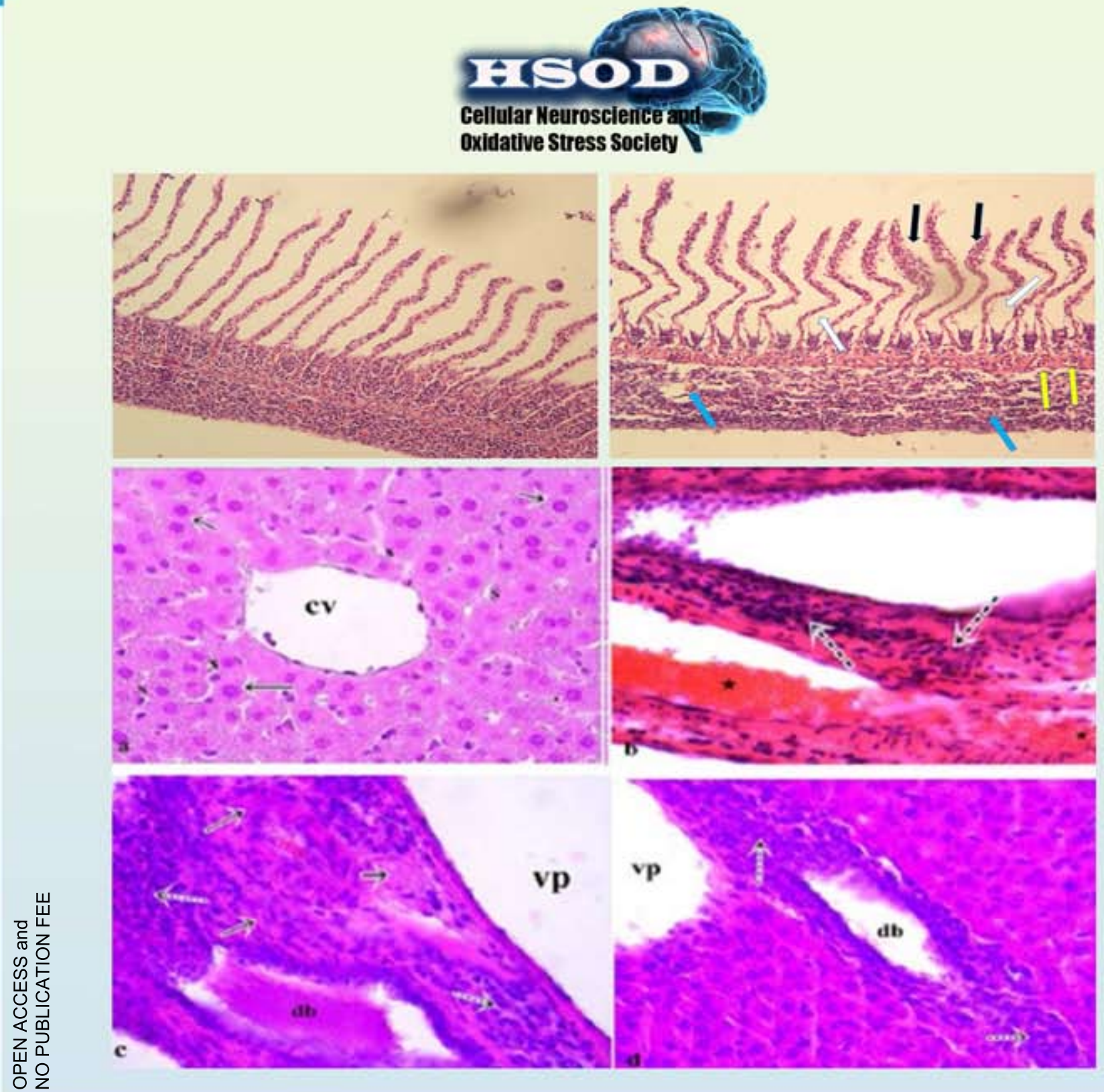

Editor in Chief Prof.Dr. Mustafa NAZIROĞLU 


\section{Journal of Cellular Neuroscience and Oxidative Stress}

http://dergipark.gov.tr/jcnos

An Official Journal of the Cellular Neuroscience and Oxidative Stress Society http://hsord.org.tr/en/

\section{Formerly known as:}

Cell Membranes and Free Radical Research (2008 - 2014)

\section{Volume 10, Number 1, 2018}

\section{[CONTENTS ]}

647 The effects of CAPE on oxidative stress and histopathological values in rats treated with subacute dichlorvos Gökhan Nur, Aysel Güven, Pınar Aksu Kıllıçle

656 Histopathological and biochemical responses to the oxidative stress induced by glyphosate-based herbicides in the rainbow trout (Oncorhynchus mykiss) Gökhan Nur, Haci Ahmet Deveci 


\section{EDITOR IN CHIEF}

Prof. Dr. Mustafa Nazıroğlu,

Department of Biophysics and Neurosciences, Medical Faculty, Suleyman Demirel University, Isparta, Turkey.

Phone: +90 24621136 41, Fax:+90 2462371165

E-mail: mustafanaziroglu@sdu.edu.tr

\section{Managing Editors}

Bilal Çiğ and Yener Yazğan

Department of Biophysics, Medical Faculty, Suleyman Demirel University, Isparta, Turkey.

E-mail: biophysics@sdu.edu.tr

\section{Editorial Board}

Neuronal Membranes, Calcium Signaling and TRP Channels

Alexei Tepikin, University of Liverpool, UK.

Ammar Boudaka, Sultan Qaboos University,

Muscat, Oman.

Jose A. Pariente, University of Extremadura,

Badajoz, Spain.

James W. Putney, Jr. NIEHS, NC, USA.

Laszlo Pecze, University of Fribourg, Switzerland.

Stephan M. Huber, Eberhard-Karls University,

Tubingen, Germany.

\section{Neuroscience and Cell Signaling}

Denis Rousseau, Joseph Fourier, University,

Grenoble, France.

Makoto Tominaga, National Institute for Physiological Sciences (NIPS) Okazaki, Japan.

Ömer Çelik, Süleyman Demirel University, Turkey.

Ramazan Bal, Gaziantep University, Turkey.

Saeed Semnanian, Tarbiat Modares University,

Tehran, Iran.

Yasuo Mori, Kyoto University, Kyoto, Japan.

\section{Antioxidant and Neuronal Diseases}

Suresh Yenugu, Osmania University, Hyderabad, India. Süleyman Kaplan, Ondokuz Mayıs Univesity,

Samsun, Turkey.

Özcan Erel, Yıldırım Beyazıt University,

Ankara, Turkey.

Xingen G. Lei, Cornell University, Ithaca, NY, USA.

Valerian E. Kagan, University of Pittsburg, USA.

Antioxidant Nutrition, Melatonin and Neuroscience Ana B. Rodriguez Moratinos, University of

Extremadura, Badajoz, Spain.

Cem Ekmekcioglu, University of Vienna, Austria.

Peter J. Butterworth, King’s College London, UK.

Sergio Paredes Department of Physiology, Madrid

Complutense University, Spain.

\section{AIM AND SCOPES}

Journal of Cellular Neuroscience and Oxidative Stress is an online journal that publishes original research articles, reviews and short reviews on the molecular basis of biophysical, physiological and pharmacological processes that regulate cellular function, and the control or alteration of these processes by the action of receptors, neurotransmitters, second messengers, cation, anions, drugs or disease.

Areas of particular interest are four topics. They are;

A- Ion Channels $\left(\mathrm{Na}^{+}-\mathrm{K}^{+}\right.$Channels, $\mathrm{Cl}^{-}$channels, $\mathrm{Ca}^{2+}$ channels, ADP-Ribose and metabolism of NAD ${ }^{+}$, PatchClamp applications)

B- Oxidative Stress (Antioxidant vitamins, antioxidant enzymes, metabolism of nitric oxide, oxidative stress, biophysics, biochemistry and physiology of free oxygen radicals)

\section{C- Interaction Between Oxidative Stress and Ion Channels in Neuroscience}

(Effects of the oxidative stress on the activation of the voltage sensitive cation channels, effect of ADP-Ribose and $\mathrm{NAD}^{+}$on activation of the cation channels which are sensitive to voltage, effect of the oxidative stress on activation of the TRP channels in neurodegenerative diseases such Parkinson's and Alzheimer’s diseases)

\section{D- Gene and Oxidative Stress}

(Gene abnormalities. Interaction between gene and free radicals. Gene anomalies and iron. Role of radiation and cancer on gene polymorphism)

$\begin{array}{ll}\text { READERSHIP } & \\ \text { Biophysics } & \text { Biochemistry } \\ \text { Biology } & \text { Biomedical Engineering } \\ \text { Pharmacology } & \text { PhysiologyGenetics } \\ \text { Cardiology } & \text { Neurology } \\ \text { Oncology } & \text { Psychiatry } \\ \text { Neuroscience } & \text { Neuropharmacology }\end{array}$

Keywords

Ion channels, cell biochemistry, biophysics, calcium signaling, cellular function, cellular physiology, metabolism, apoptosis, lipid peroxidation, nitric oxide, ageing, antioxidants, neuropathy, traumatic brain injury, pain, spinal cord injury, Alzheimer's Disease, Parkinson's Disease. 


\title{
The effects of CAPE on oxidative stress and histopathological values in rats treated with subacute dichlorvos
}

\author{
Gökhan Nur ${ }^{\text {* }}$, Aysel Güven², Pınar Aksu Kılıçle ${ }^{3}$ \\ ${ }^{1}$ Department of Veterinary, İslahiye Vocational High School, Gaziantep University, Islahiye, Gaziantep. \\ ${ }^{2}$ Pathology Laboratory Technicians, Vocational School of Healthcare Services, Başkent University, Ankara, Turkey. \\ ${ }^{3}$ Department of Biology, Faculty of Science and Arts, Kafkas University, Kars, Turkey.
}

Received December 6, 2017; Accepted January 20, 2017

\begin{abstract}
This study was designed to investigate the protective effect of CAPE against dichlorvos induced hepatotoxicity in rats. 40 rats were used in the study, including 10 in each group. Corn oil of $5 \mathrm{mg} / \mathrm{kg}$ (solvent) was administered intragastrically to rats in the group 1, dichlorvos of $5 \mathrm{mg} / \mathrm{kg}$ was dissolved in corn oil and administered to rats in the group 2 via gavage, dichlorvos ( $5 \mathrm{mg} / \mathrm{kg}$, via gavage route) and CAPE (10 $\mu \mathrm{M} / \mathrm{kg}$, intraperitoneally) were administered to rats of the group 3 with one-hour interval providing that CAPE treatment was started three days earlier than dichlorvos administration.
\end{abstract}

*Author for correspondence :

Assist. Prof. Dr. Gökhan NUR

Department of Veterinary, Islahiye Vocational High School, Gaziantep University, Gaziantep, Turkey.

Tel: + 905068068731

E-mail: gokhannur@gantep.edu.tr

\section{List of Abbreviations;}

CAPE, Caffeic acid phenethyl ester; PON, Paraoxonase; HDL, High density lipoprotein cholesterol; ROS, Reactive oxygen species; LDL, Low density lipoprotein cholesterol; TAS, Total antioxidant status; TOS, Total oxidant status; ABTS, 2,2'azino-bis (3-etilbenzthiazoline-6-sulfonic acid); AChE, Acetylcholinesterase; CV, Central veins; VP, Portal veins; DB, Ductus biliferus
The rats in the group 4 were administered with $10 \%$ solvent ethanol via intraperitoneally. All administrations continued for 15 days and blood of animals was drawn via intracardiac route after they were sacrificed by cervical dislocation under ketamine/xylazine anesthesia. Total antioxidant, total oxidant, and paraoxonase levels were measured from the obtained plasma samples. As a result of dichlorvos administration, paraoxonase activity and total antioxidant levels decreased; whereas, total oxidant levels increased. Histopathological analysis revealed that liver tissue appeared normal in control groups (1 and 4); on the other hand, there were degeneration, congestion, cellular infiltration, and necrotic areas in the group administered with dichlorvos. Even though frequency of lesions decreased, similar lesions were observed in the group with Dichlorvos+CAPE. Consequently, it was determined that while dichlorvos administration increased oxidative stress, CAPE administration had a protective potential increasing antioxidant capacity.

Keywords: Dichlorvos; CAPE; Hepatotoxicity; Oxidative stress; Subacute administration. 


\section{Introduction}

Organophosphorus drugs are the insecticides used commonly for agricultural applications, public health, workplaces and houses to ensure yield and hygienic conditions. Insecticides, which contain organic phosphorus and have the structure including one or more phosphorus atoms, is the most commonly used group among the pesticides. These compounds synthesized in 1800s and their cholinergic effects were described in 1930s and their insecticide traits were discovered and it was revealed after a while that they also could be used as an agent of chemical warfare (Hirosawa et al., 2011; Kazemi et al., 2012; Bardin et al., 1994).

There is a balance between the rate of formation of free radicals and their elimination rate in the organism and this is called as oxidative balance. Organism is not influenced by free radicals as long as oxidative balance is ensured. Increased rate of formation of these radicals or a decrease in their elimination rate leads this balance to become unbalanced (Uzer et al., 2014).

Active forms of oxygen occur during normal processes in oxygen consumption of the body and due to some chemical factors in the metabolism of living organisms. These active oxygen forms cause structural deterioration of proteins, carbohydrates, and lipids. This leads to numerous disorders by disrupting both structure and functions of cell membrane (Güven and Kaya, 2005). Dichlorvos is one of such chemical toxic substances. There are strong evidences indicating that oxidative stress arising from metabolic changes developing based on Dichlorvos contribute the development of complications of metabolic syndrome (Eyer et al., 2007; Peter 2006). It is reported that decreased Paraoxonase (PON) activity which is an antioxidant enzyme associated with high density lipoprotein (HDL) likely causes a number of degenerative deteriorations in liver ( $\mathrm{Li}$ et al., 1995; Deveci et al., 2015a).

Caffeic acid phenethyl ester (CAPE) is the active component of propolis with strong, nice odor found in the extract collected by bees from plants. This component is reported to scavenge oxygen radicals arising from metabolic activities and reactive oxygen species (ROS) generated by xanthine oxidase system (Murtaza et al., 2014; Nur et al., 2016).
Paraoxonase (PON1) is an ester hydrolase enzyme from aryldialkylphosphatase class with both aryl esterase and paraoxonase activity, which can hydrolyze paraoxone that is strong inhibitor of cholinesterase and inhibit LDL oxidation (Senti et al., 2003). PON proteins with a wide distribution among mammal species have three different neighboring PON genes on the same chromosome in human beings and rats (Hegele, 1999). PON1 is a protein responsible for the antioxidant properties of HDL. It is reported that PON1 protects both low density lipoproteins (LDL) and HDL from oxidation, PON1 inhibitors increase oxidation of HDL by inducing free radical formation and $\mathrm{Cu}^{+2}$, and also elevate release of cholesterol from macrophages (Mackness and Mackness, 2015; Deveci et al., 2017a; Litvinov et al., 2012).

The aim of the present study is to determine the effect of subacutely administered dichlorvos, which is an organophosphate insecticide, on oxidative stress in the organism and the efficacy of CAPE in preventing radicals.

\section{Materials and Methods \\ Experimental design \\ Animals}

Required ethics committee approval was provided by Kafkas University Local Ethics Committee for Animal Experiments (Decision No: KAÜHADYEK/2017-093) before the study. Forty Sprague Dawley adult male rats were used as the study material. The rats were fed ad libitum with standard rat diet in the form of pellet and ensured to consume potable water freely. The rats were kept in an environment with 12hour light/12-hour darkness cycle, $20-22^{\circ} \mathrm{C}$, and an average humidity of $45-60 \%$.

\section{Study groups}

\section{Groups were as follows;}

Group I: Corn oil of $5 \mathrm{ml} / \mathrm{kg}$ was orally administered via gavage to the rats in this group for 15 days (Control 1).

Group II: After being dissolved in corn oil, dichlorvos of $5 \mathrm{mg} / \mathrm{kg}$ was administered to the rats in this group via gavage for 15 days.

Group III: CAPE was started to be administered 3 days before dichlorvos administration to the rats in this group. Afterwards, $10 \mu \mathrm{M} / \mathrm{kg}$ dose of CAPE (Sigma) 
dissolved within $10 \%$ ethanol was administered intraperitoneally $(0.5 \mathrm{ml}$.) for 15 days, then dichlorvos (5 mg/kg) was orally administered via gavage 1 hour later.

Group IV: 10\% ethanol, which is the solvent of CAPE, was administered intraperitoneally to the rats in this group (0.5 ml.) (Control 2).

Blood was taken intracardially when animals were under ketamine/xylazine anesthesia and killed with cervical dislocation. Blood samples were then centrifuged at $3000 \mathrm{rpm}$ for 10 minutes and the resulting plasma were stored at $-20{ }^{\circ} \mathrm{C}$. The liver tissues were examined by light microscopy for histological changes by taking thin sections after routine tissue-following steps.

\section{Biochemical Analyses}

Paraoxonase (PON1) activity assay:

PON1 activity assay was carried out according to the methods of Eckerson et al., (1983), and Gülcü and Gürsu (2003). PON1 activity was determined via spectrophotometric measurement of absorbance (at 25 ${ }^{\circ} \mathrm{C}$ and 412 nanometer) of the colored product, yielded from 4-nitrophenol occurring as a result of enzymatic hydrolysis of paraoxone (Sigma Co, London, UK) which was used as substrate. For paraoxonase activity, enzyme activity of enzyme in $1 \mathrm{ml}$ serum transforming $1 \mathrm{nmol}$ paraoxone into 4- nitrophenol in 1 minute was described as unit and the results were given in $\mathrm{U} / \mathrm{L}$.

\section{Total antioxidant status (TAS) assay:}

TAS was determined by using automatic measurement method based on decolorization of characteristic color generated by 2,2'azino-bis (3etilbenz-thiazoline-6-sulfonic acid) (ABTS) radical via antioxidants in sample that was added into medium (Erel, 2004). The results were given in mmol Trolox equivalent/L.

\section{Total oxidant status (TOS) assay:}

TOS was determined via automatic measurement method (Erel 2005). Oxidants in sample transform ferrous ion complex into ferric ion. Ferric ion $\left(\mathrm{Fe}^{3+}\right)$ occurring by oxidation of iron $\left(\mathrm{Fe}^{2+}\right)$ into its more stabile form $\left(\mathrm{Fe}_{2} \mathrm{O}_{3}\right)$ creates color reaction with xylenol orange in acidic medium. Intensity of color measured spectrophotometrically is associated with total amount of oxidant molecules found in the sample. Measurement was calibrated with hydrogen peroxide $\left(\mathrm{H}_{2} \mathrm{O}_{2}\right)$ and the results were given in micromolar $\mathrm{H}_{2} \mathrm{O}_{2}$ equivalent per liter ( $\mu \mathrm{mol} \mathrm{H}_{2} \mathrm{O}_{2}$ equiv./L).

\section{Histological Analyses}

Liver tissue was fixed within bouin and $10 \%$ formol solutions. $5 \mu \mathrm{m}$ thick cross sections were taken by microtome embedding the tissues into paraffin after routine tissue processing (grade alcohols, methyl benzoate, and benzole processing) following the fixation. Histopathological changes were examined under light microscope by staining cross sections with hematoxylin -eosin among histological staining methods (Luna, 1968).

\section{Data Analyses}

Statistical analysis of the data obtained from the study was carried out using SPSS packaged software (IBM SPSS Statistic 22). One way variance analysis (ANOVA) was applied to determine whether or not there was difference between means of experimental groups and if there was difference between means of experimental groups, “Anova-Duncan” test was used on group means to identify which group or groups caused this difference and the value of $\mathrm{p}<0.05$ was accepted as statistically significant.

\section{Results}

\section{Biochemical Results}

Blood of animals was drawn as intracardiac after they were sacrificed by cervical dislocation under ketamine/xylazine anesthesia. Total antioxidant, total oxidant, and paraoxonase levels were measured from plasma samples. As a result of statistical comparison of biochemical data of the groups; it was found that while there was no difference between control 1 (oil) and control 2 (ethanol) in terms of paraoxonase activity, there was also no difference between the dichlorvos and dichlorvos+CAPE groups $(p>0.05)$. The difference between control groups (1 and 2) and dichlorvos and dichlorvos+CAPE groups was statistically significant $(\mathrm{p}<0.01)$. In terms of total antioxidant capacity, the control 1 (oil), dichlorvos and dichlorvos+CAPE groups were different from each other $(\mathrm{p}<0.01)$. The difference between control 2 (ethanol) and control 1 (oil) groups was insignificant. The difference between control 2 
(ethanol) and dichlorvos+CAPE groups was insignificant $(\mathrm{p}>0.05)$. There was a statistically significant difference between Dichlorvos group and the remaining 3 groups $(\mathrm{p}<0.01)$. In evaluation of total oxidant capacity, there was no difference between control 2 (ethanol), control 1 (oil), and dichlorvos+CAPE groups, but the difference between the dichlorvos group and the remaining 3 groups was significant $(\mathrm{p}<0.01)$ (Table 1$)$.
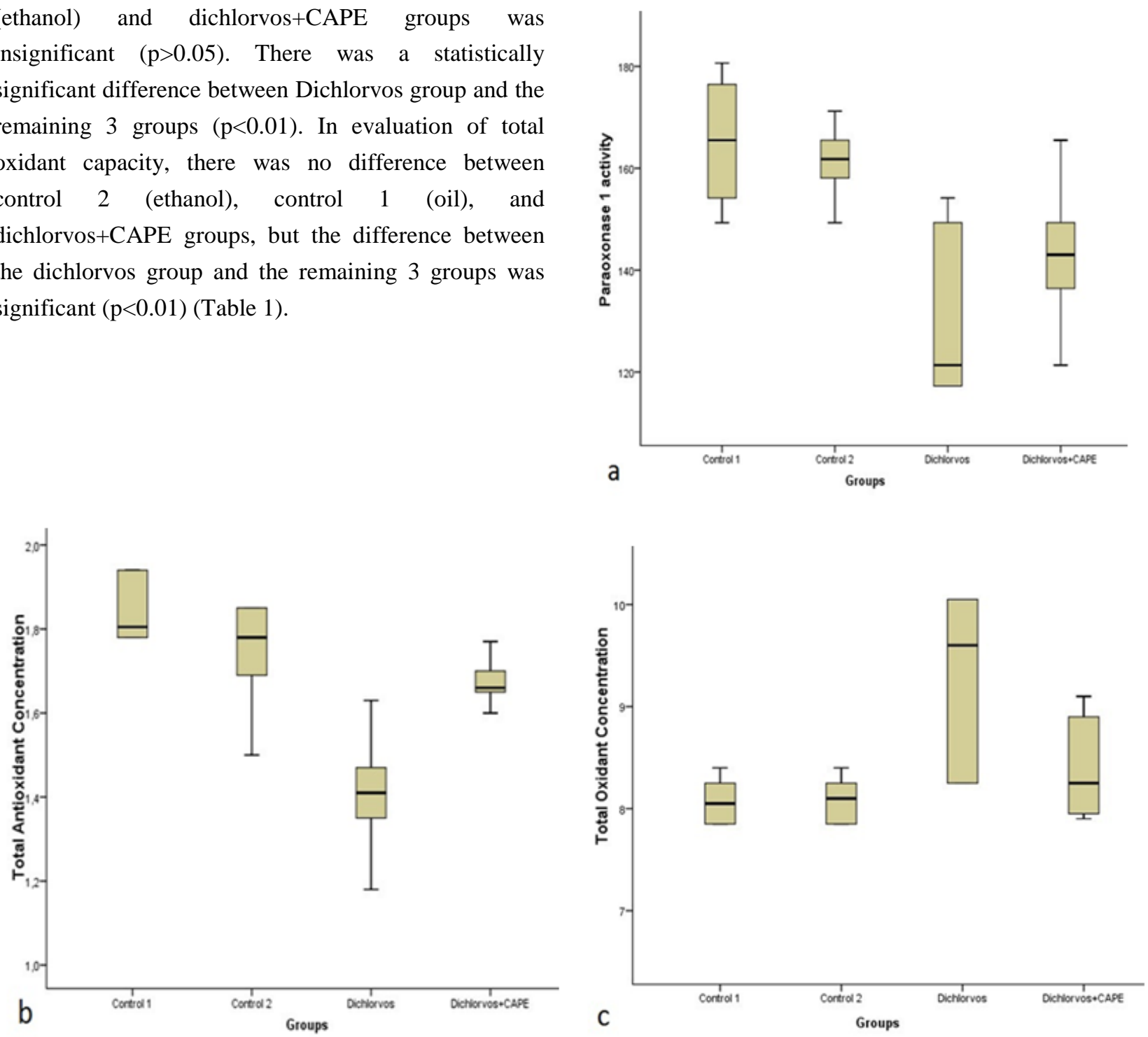

Fig. 1. Box plot display of CAPE on TAS, TOS and PON values in rats treated with subacute dichlorvos a. PON1 activity, b. TAS, c. TOS.

\begin{tabular}{|c|c|c|c|c|c|}
\hline \multirow[t]{2}{*}{ Parameters } & \multicolumn{5}{|c|}{ Groups (n:10) } \\
\hline & $\begin{array}{l}\text { Control l (oil) } \\
\text { (Mean } \pm \text { SD) }\end{array}$ & $\begin{array}{c}\text { Control } 2 \text { (ethanol) } \\
(\text { Mean } \pm \text { SD) }\end{array}$ & $\begin{array}{c}\text { Dichlorvos } \\
(\text { Mean } \pm \text { SD) }\end{array}$ & $\begin{array}{c}\text { Dichlorvos + CAPE } \\
(\text { Mean } \pm \text { SD) }\end{array}$ & p \\
\hline PON (U/L) & $166.41 \pm 11.06^{\mathrm{a}}$ & $161.18 \pm 7.94^{\mathrm{a}}$ & $130.60 \pm 16.26^{b}$ & $142.01 \pm 14.13^{b}$ & * \\
\hline TAS (mmol Trolox Eqv./L) & $1.84 \pm 0.07^{\mathrm{s}}$ & $1.75 \pm 0.10^{a b} b$ & $1.39 \pm 0.13^{c}$ & $1.67 \pm 0.06^{b}$ & * \\
\hline $\mathrm{TOS}\left(\mu \mathrm{mol} \mathrm{H} \mathrm{H}_{2} \mathrm{O}_{2} \mathrm{Eqv} / \mathrm{L}\right)$ & $7.89 \pm 0.56^{b}$ & $8.04 \pm 0.51^{b}$ & $9.37 \pm 0.80^{\mathrm{s}}$ & $8.43 \pm 0.47^{b}$ & * \\
\hline
\end{tabular}

${ }^{*} p<0.01$ : Statistically significant difference, $a, b, c$ : Horizontally, values with different letter indicate significant differences, SD: Standart deviation

Table 1. Effect of CAPE on TAS, TOS and PON values in rats treated with subacute dichlorvos (mean \pm SD and $n=10)$. 


\section{Histopathological Results}

In the present study, histological examinations of liver tissues in control groups (control 1 and 2), which were administered with solvents of chemicals used for liver tissue samples (control 1 and 2) in histological examinations based on oxidative stress factors in rats administered with subacute dichlorvos, revealed that Vena centralis and portal region (Vena interlobularis, Arteria hepatica, Ductus biliferus) had normal appearance and hepatocyte arrangement was regular (Figure 2 a, 1). There were a few number of mononuclear cell infiltrations around central and portal region (kiernan's space) and mild congestion which was more intense for vena in portal region in the group administered with ethanol.
Liver tissue obtained from the group administered with dichlorvos was found to have degeneration, congestion in central vena, mononuclear cell infiltrations around vena, irregularity in remark cell cords between central and portal region, and areas of focal necrosis. Congestion was observed in interlobular vein and intense mononuclear and polymorphonuclear cell infiltrations were observed around portal region (Figure 2 b, c, d). Congestion and cell infiltration were determined in central and interlobular vein in liver cross sections obtained from the dichlorvos+CAPE groups. Compared to the dichlorvos group, severity and frequency of histological changes decreased (Figure 2 e, f, g, h).
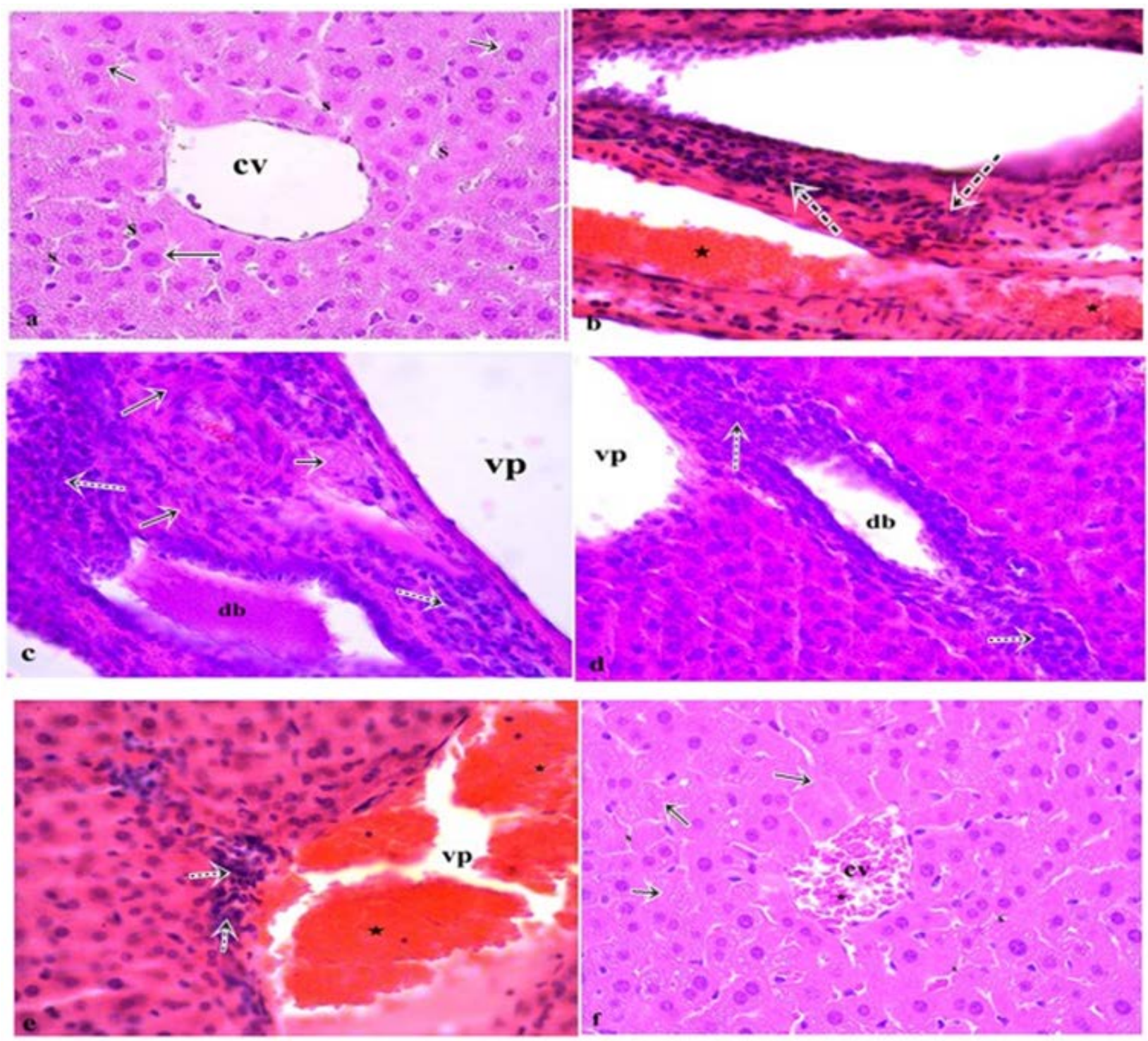

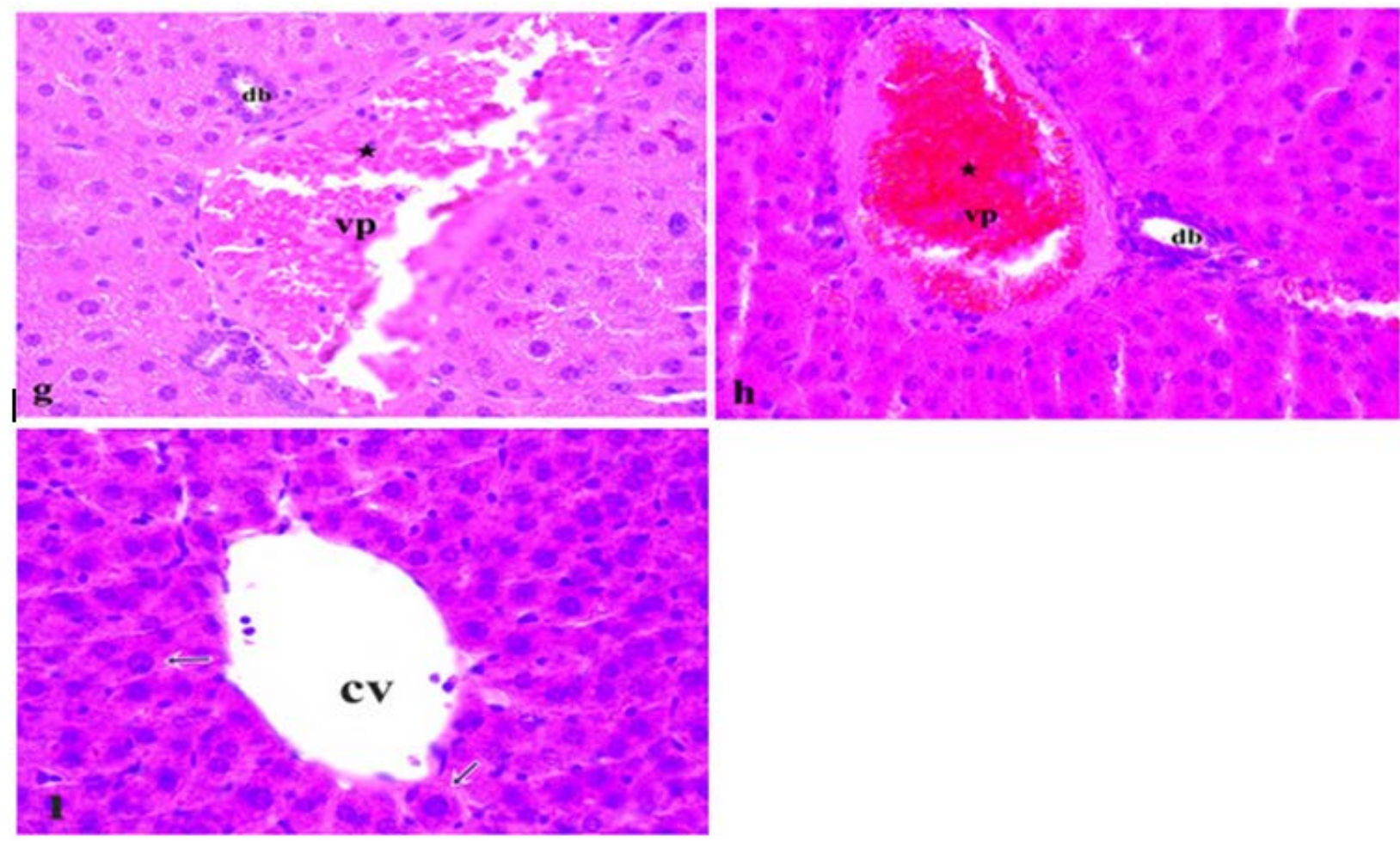

Figure 2. The effect of CAPE (10 $\mathrm{MM} / \mathrm{kg})$, corn oil $(5 \mathrm{mg} / \mathrm{kg})$ and dichlorvos $(5 \mathrm{mg} / \mathrm{kg})$ either separately or $1 \mathrm{~h}$ after dichlorvos group's histology of liver section by using hematoxylin and eosin staining (H\&E): (a) control 1, (1) control 2; hepatocytes (arrows), s: sinusoid, cv: central veins, vp: portal veins (b, c, d) dichlorvos; severe central and portal congestion (asterisks), cell infiltrations (split arrows), focal necrosis and degenerative areas (arrows), db: ductus biliferus, (e, f, g, h) dichlorvos+CAPE; severe central and portal congestion (asterisks).

\section{Discussion}

Even though acute toxicity of organophosphates is higher (Costa et al., 1990), their breakdown by photolysis and hydrolysis has provided these compounds to become alternatives to persistent Organochloride pesticides such as DDT, aldrin, and dieldrin; their use has become much wider after prohibition of organ-chloride pesticides in several countries in 1970s. Action mechanisms of all organophosphate compounds work with inhibition of acetylcholinesterase (AChE) enzyme, in other words they all display neurotoxic effect. Therefore, AChE activity and lipid peroxidation are used as biomarker for determination of organophosphate pesticide pollution (Vasseur and Cossu-Leguille, 2003). It is known that while AChE inhibition varied based on dose and time, inhibition rate is also differed in terms of the species and tissue. 50\% or higher inhibition in AChE activity may lead to death (Day and Scott, 1990); an inhibition of $20 \%$ is the indicator for exposure (Dembélé et al.,
2000).

There was an interaction between CAPE treatment and PON1 activity, total antioxidant status (TAS), and total oxidant status (TOS) for poisoning of dichlorvos which is an organo-phosphate compound. A great majority of the related studies involve animal researches (Alp et al., 2016; Celik et al., 2015; Kaur et al., 2007; Mutlu et al., 2011; El-Raof Mohammad et al., 2014).

While PON1 and TAS levels decreased and TOS level increased in rats in dichlorvos group in the present study, PON1 and TAS levels increased and TOS level decreased in the Dichlorvos+CAPE group based on oxidative stress reduced by CAPE. This supports the idea; administration of CAPE and dichlorvos decreased the stress to be caused by dichlorvos in the organism by contributing to enzymatic and non-enzymatic antioxidants and increasing TAS level. In their study, Ozkan et al., (2014) reported that CAPE had a protective characteristic as antioxidant, caused an increase in declined TAS levels in toxic substance 
administrations, and a decrease in elevated TOS levels. PON1 enzyme purified from serum of rabbits and injected intravenously to rats was stated to increase PON1 activity of the rats by 9 times compared to paraoxone (Costa et al., 1990). Related studies have showed that there was a negative correlation between organophosphate poisoning and PON1 levels (Akgür et al., 2003; Costa et al., 1990).

Detoxification of organophosphate compounds in living organisms; is carried out by enzymes such as acetylcholinesterase, carboxylesterase, and paraoxonase. The enzyme is found in other tissues, although it is found mostly in the liver. These enzymes hydrolyzing organophosphates are found to be associated with HDL in liver, kidney, intestines, and serum and also directly affect these organs (Litvinov et al., 2012; Watson et al., 1995; Deveci et al., 2017a, Deveci et al., 2017b). A study investigating efficacy of CAPE against dichlorvos administration revealed that dichlorvos decreased antioxidant level while increasing total oxidant status. In the same study, dichlorvos increased the number of mitotic cell and apoptotic cell in liver tissue, but CAPE decreased the number of these cell due to its protective traits (Alp et al., 2016). Dichlorvos, applied in both studies, increased antioxidant capacity while increasing total oxidant level. The data obtained by Alp in his study, support the results of our study. Dichlorvos applied in both studies decreased the antioxidant capacity while increasing total oxidant level. As cells are exposed to apoptosis and necrosis, degenerative areas have formed in the liver tissue. In both studies, the use of CAPE increased the antioxidant capacity and therefore the severity and frequency of lesions in the liver tissue decreased. Both studies are different in dichlorvos doses and duration of implementation. The duration of acute implementation (dose $4 \mathrm{mg} / \mathrm{kg}$ ) was in Alp's study whereas in our study the duration of subacute implementation (15 days, dose $5 \mathrm{mg} / \mathrm{kg}$ ) was applied.

While PON activity and TAS levels decreased significantly in the group administered with dichlorvos $(p<0.01)$, TOS levels increased significantly. This makes us think that it occurred by production of ROS associated with dichlorvos toxicity in blood and liver. Observation of an opposite situation in CAPE group confirms that CAPE has a healing/ therapeutic effect against oxidative damage. In a study on dichlorvos- induced nephrotoxicity; it was found that while total antioxidant status decreased significantly in the dichlorvos group, it increased in dichlorvos+CAPE group compared to the dichlorvos group. Likewise, dichlorvos increased oxidant level; whereas, oxidant status decreased in dichlorvos+CAPE group compared to dichlorvos group. The number of mitotic cell and apoptotic cell in kidney tissue increased based on oxidative stress elevated by dichlorvos. On the other hand, the number of mitotic cell and apoptotic cell was determined to decrease in CAPE group immediately after dichlorvos treatment. This result indicated that CAPE reduced oxidative stress (Celik et al., 2015).

There are numerous studies reporting that low PON activity triggers several disorders and causes increased oxidative stress, and this lead to various pathological changes on liver. It is reported that PON1 is not only based on blood or tissue levels but also its isomers and also it shows different variances in every organism. PON1 contributes to the antioxidant functions of HDL and a decrease in HDL-PON1 activity may trigger inflammation. This protective effect of HDL on LDL oxidation is thought to be associated with PON1 (Litvinov et al., 2012; Mackness and Mackness, 2015; Deveci et al., 2015b, Deveci et al., 2017a, Deveci et al., 2017c). When considering the data obtained from the present study, TAC and PON levels decreased and TOS level increased based on oxidative stress factors in rats administered with subacute dichlorvos. Free radicals occurring based on oxidative stress in the organism when metabolizing dichlorvos decreased TAS levels, administration of CAPE and dichlorvos increased plasma TAS levels by contributing enzymatic and nonenzymatic antioxidants.

In conclusion, results obtained from the present study revealed that CAPE was antioxidant and had traits of decreasing or eliminating free radicals. It was indicated in the present study that dichlorvos, which is an organophosphorus pesticide, generated oxidative stress on liver and blood by producing free radicals and negatively influenced cellular antioxidant defense system.

\section{Acknowledgement}

There is no financial support for the study. Dr. Nur, Dr. Güven and Dr. Aksu Kılıçle researched literature and conceived the study. They were involved 
in protocol development, gaining ethical approval, experimental design. Data analysis was completed by whole authors. All authors reviewed and edited the manuscript and approved the final version of the manuscript.

\section{References}

Akgür SA, Öztürk P, Solak I, Moral AR, Ege B. 2003. Human serum paraoxonase (PON1) activity in acute organophorous insecticite poisoning. Forensic Sci Int. 133:136-140.

Alp H, Pinar N, Dokuyucu R, Sahan M, Oruc C, Kaplan I, Senol S, Ceyran AB. 2016. Protective effects of intralipid and caffeic acid phenethyl ester (CAPE) on hepatotoxicity and pancreatic injury caused by dichlorvos in rats. Biochem Genet. 54:803815.

Bardin PG, Van Eeden SF, Moolman JA, Foden AP, Joubert, JR. 1994. Organophosphate and carbamate poisoning. Arc Intern Med. 154(13):1433-1441.

Celik MM, Alp A, Dokuyucu R, Zemheri E, Ozkanlı S, Ertekin F, Yaldız M, Akdağ A, Ipci O, Toprak S. 2015. Protective effects of intralipid and caffeic acid phenethyl ester on nephrotoxicity caused by dichlorvos in rats. J Anal Methods Chem. Article ID 491406, 2015:1-8,

Costa LG, Mcdonald BE, Murphy SD, Omenn GS, Richter RJ, Motulsky AG, Furlong CE. 1990. Serum paraoxonase and its influance on paraoxon and and chlorpyrifos-oxon toxicity in rats. Toxicol Appl Pharmacol. 103:66-76.

Day KE, Scott IM. 1990. Use of asetylcholinesterase activity to detect sublethal toxicity in stream invertebrates exposed to low concentrations of organophosphate insecticides. Aquatic Toxicology. 18:101-114.

Dembélé K, Haubruge, E, Gaspar C. 2000. Concentration effects of selected insecticides on brain acetylcholinesterase in the common carp (Cyprinus carpio L.). Ecotoxicol Environ Saf. 45(1):49-54.

Deveci HA, Nur G, Alpay M, Özmerdivenli R. 2017a. Levels of paraoxonase, high-density lipoprotein and total sialic acid in patients with polycystic over syndrome. J Cell Neurosci Oxid Stress. 9(2):630-636.

Deveci HA, Nur G, Kukurt A. 2017b. Biochemical and histopathological changes of babesiosis in naturally infected sheep in Gaziantep region. Fresen Environ Bull. 26(7):48834889.

Deveci HA, Nur G, Çiçek H, Karapehlivan M. 2017c. Evaluation of oxidative stress factors in patients with osteoporosis. Medicine Science. 6(3):479-82.

Deveci HA, Karapehlivan M, Kaya İ, Kükürt M. 2015a. Protective effect of caffeic acid phenethyl ester against acute chlorpyrifosethyl poisoning, In Turkish. Ankara Üniv Vet Derg. 62:255260.

Deveci HA, Kaya İ, Yılmaz M, Karapehlivan M. 2015b. Effect of zinc sulphate on the levels of plasma paraoxonase activity, total oxidant and high density lipoprotein of transcaucasian barb (Capoeta capoeta [Gulbenstaedt, 1773]). Fresen Environ Bull. 24(9):2732-2735.

Erel O. 2004. A novel automated direct measurement method for total antioxidant capacity using a new generation, more stable abts radical cation. Clin Biochem. 37:277-285.

Erel O. 2005. A new automated colorimetric method for measuring total oxidant status. Clin Biochem. 38:1103-1111.

Eckerson HW, Romson J, Wyte CM, La Du BN. 1983. The human serum paraoxonase polymorphism: Identification of phenotypes by their response to salts. Am J Hum Genet. 35:214-227.

El-Raof Mohammad AA, Gharib OA, El-Din Amin N, Moustafa YM. 2014. Rol of caffeic acid phenethyl ester on 1-nitropyrene and/or gamma irradiaton induce oxidative damage in rats. Spatula DD. 4(1):17-25.

Eyer P, Szinicz L, Thiermann H, Workek F, Zilker T. 2007. Testing of antidotes for organophjosphours compounds: Experimental procedures and clinical reality. Toxicology. 233:108-119.

Gülcü F, Gürsu MF. 2003. Standardization of paraoxonase and aryl esterase activity measurements, In Turkish. Turk J Biochem. 28:45-49.

Güven A, Kaya N. 2005. Determination of reducte glutathione (GSH), glutathione S-transferase (GST) and selenium (Se) levels in goose liver cells with damage induced by carbon tetrachloride $\left(\mathrm{CCl}_{4}\right)$ and ethanol $\left(\mathrm{C}_{2} \mathrm{H}_{5} \mathrm{OH}\right)$. Turk J Vet Anim Sci. 29:12331238.

Hegele RA. 1999. Paraoxonase genes and disease. Ann Med. 31:217224.

Hirosawa N, Ueyama J, Kondo T, Kamijima M, Takagi K, Fujinaka S, Hirate A, Hasegawa T, Wakusawa S. 2011. Effect of DDVP on urinary excretion levels of pyrethroid metabolite 3phenoxybenzoic acid in rats. Toxicol Lett. 203(1):28-32.

Kaur P, Radotra B, Minz RW, Gill KD. 2007. Impaired mitochondrial energy metabolism and neuronal apoptotic cell death after chronic dichlorvos (OP) exposure in rat brain. Neurotoxicology. 28(6):1208-1219.

Kazemi M, Tahmasbi R, Valizadeh R, Naserian AA, Soni A. 2012. Organophosphate pesticides: A general review. Agric Sci Res J. 2(9):512-522.

Li WF, Furlong C, Costa LG. 1995. Paraoxonase protects against chlorpyrifos toxicity in mice. Toxicol Lett. 76(3):219-226.

Litvinov D, Manihi H, Garelnabi M. 2012. Antioxidant and antiinflammatory role of paraoxonase 1: Implication in arteriosclerosis diseases. N Am J Med Sci. 4(11)-523-532.

Luna LG. 1968. Manual of histologic staining methods of armed forces institute of pathology. Third Ed. MC. Graw. Hill Book Comp. London.

Murtaza G, Karim S, Akram MR, Khan SA, Azhar S, Mumtaz A, Bin Asad MHH. 2014. Caffeic acid phenethyl ester and therapeutic potentials. BioMed Research International. 2014:1-9.

Mutlu N, Ersan Y, Nur G, Koc E. 2011. Protective effect of caffeic acid phenethyl ester against lead acetate-induced hepatoxicity in mice. Kafkas Univ Vet Fak Derg. 17(Suppl A):1-5.

Nur G, Deveci HA, Ersan Y, Merhan O, Nazlı M, Nur Ö. 2016. Protective role of caffeic acid phenethyl ester against tetramethrine-induced toxicity in mice. Medicine Science. 5(4):972-8

Ozkan U, Osun A, Basarslan K, Senol S, Kaplan I, Alp H. 2014. Effects of intralipid and caffeic acid phenethyl ester on neurotoxicity, oxidative stres, and acetylcholinesterase activity in acute chlorpyriphos intoxication. Int J Clin Exp Med. 7:837- 
846.

Peter JV, Moran JL, Graham P. 2006. Oxime therapy and outcomes in human organophosphate poisoning: An evaluation using metaanalytic techniques. Crit Care Med. 34:502-510.

Senti M, Tomas M, Fito M, Weinbrenner T, Covas MI, Sala J, Masia R, Marrugat J. 2003. Antioxidant paraoxonase-I activitiy in the metabolic syndrome. J Clin Endocrinol Metab. 88(11):54225426.

Uzer E, Varol S, Acar A, Firat U, Basaraslan SK, Evliyaoglu O, Yücel Y, Alp H, Gökalp O. 2014. Assesment the role of oxidative stress and efficacy of caffeic acid phenethyl ester (CAPE) on neurotoxicity induced by isonizaid and ethambutol in a rat model. Eur Rev Med Pharmacol Sci. 18(19):2953-9.

Vasseur P, Cossu-Leguille C. 2003. Biomarkers and community indices as complementary tools for environmental safety. Environ Int. 28(8):711-717.

Watson AD, Berliner JA, Rama SY, La Du BN, Faul KF, Fogelman AM, Navab M. 1995. Protective effect of high density lipoprotein associated paroxonase: Inhibition of the biological activtiy of minimally oxidized low density lipoprotein. J Clin Invest. 96:2882-2891. 
7 Wणrd Corgress Oxidative Stress, Calcium Signaling and TRP Channels

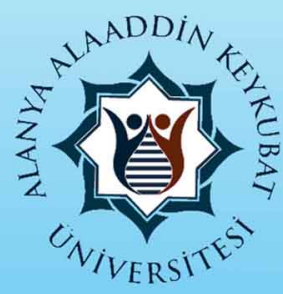

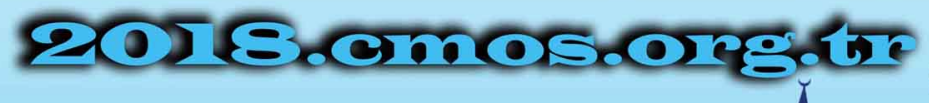

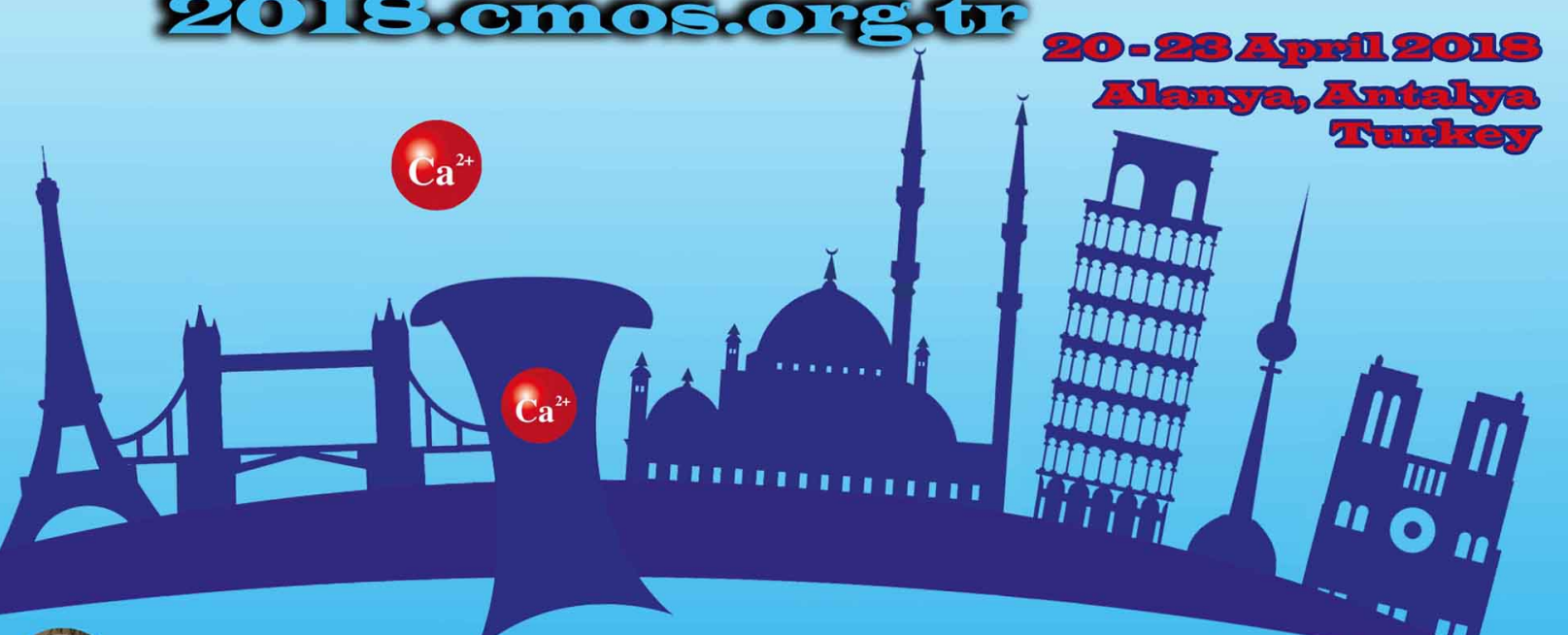

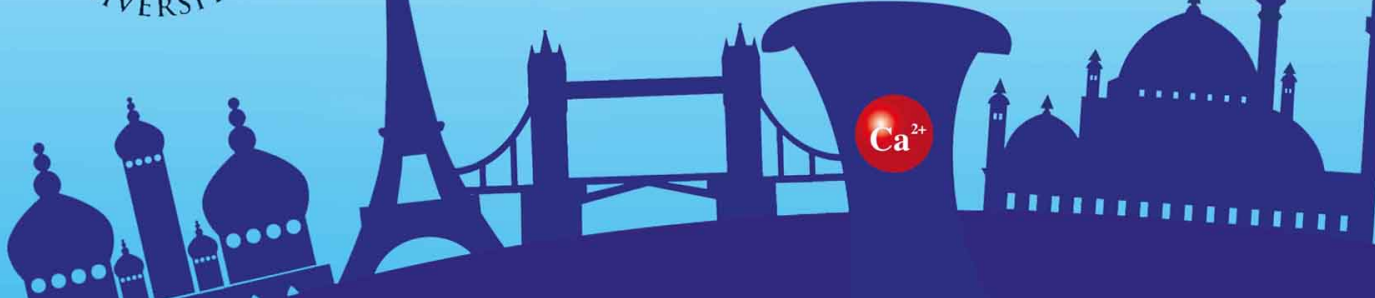
win....

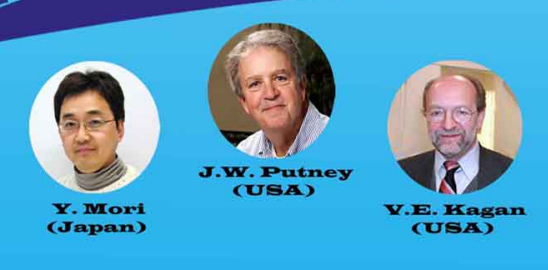

(2) the

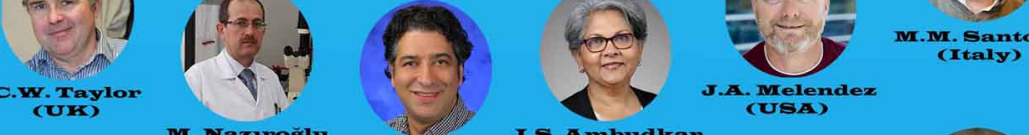
$\ldots$

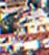

(19)

J.H. Jaggax
(USA)

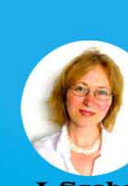

$\frac{1}{2} y^{2}$

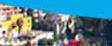

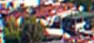

1).

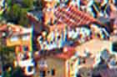

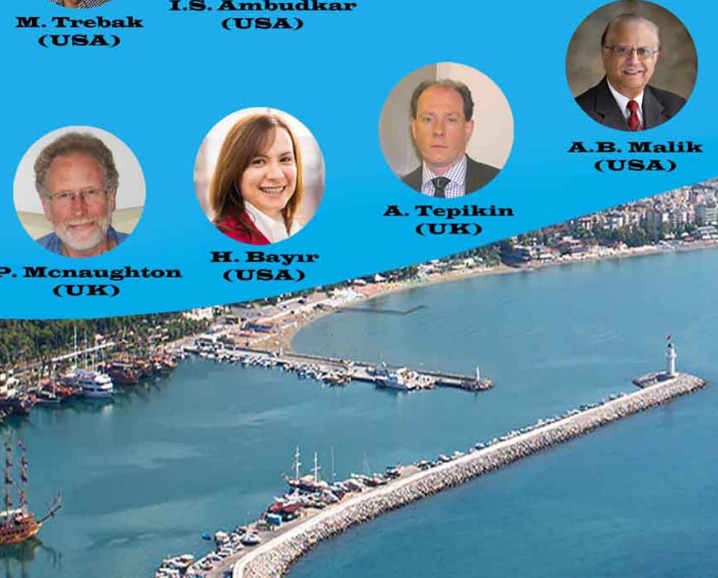

Ca
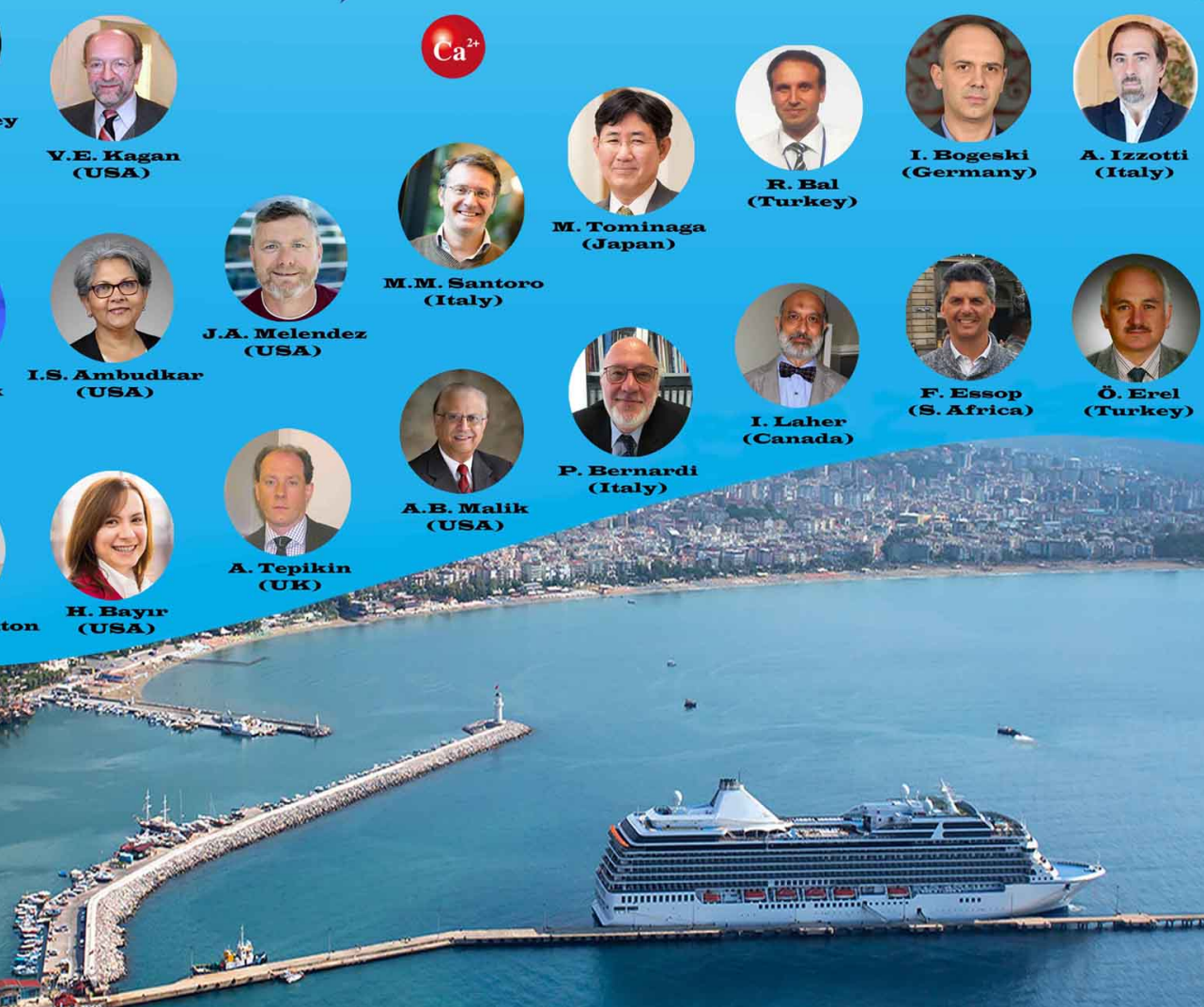

40
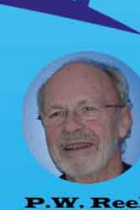

P.W. Feeh
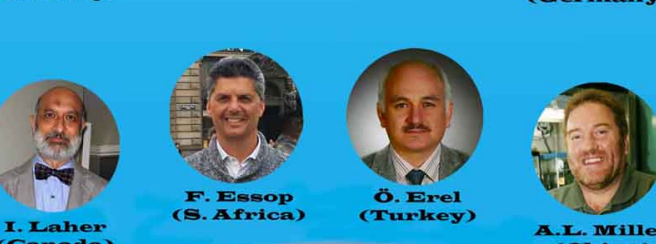

(China)

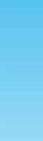

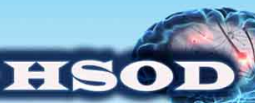

Gellular Neuroscienter ant

Oxidative Stress Society
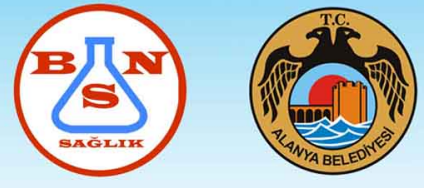

EFTALIA

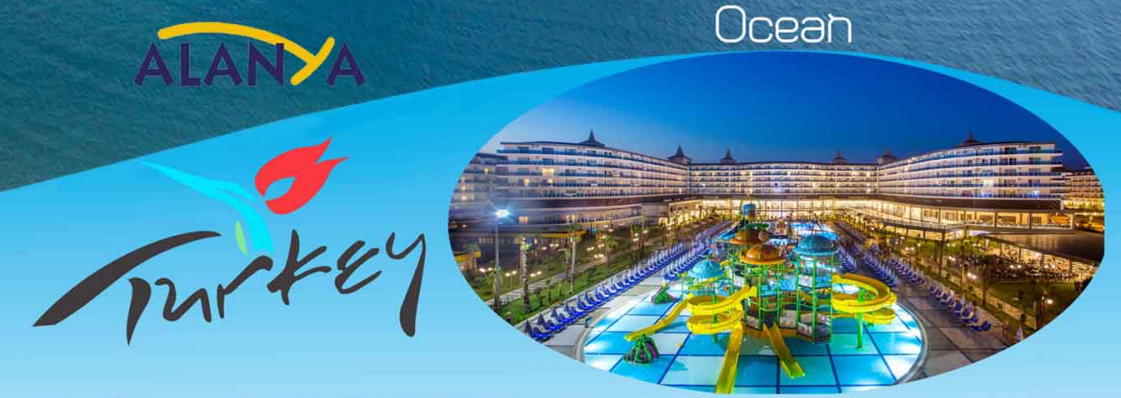

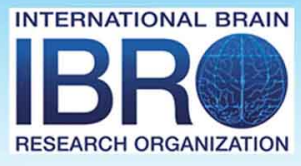
EBSA
ZDINS
Contact:
mail: cmos@sdu.edu.tr Tel: $\quad+902462113641$
Fax: +902462371165! 


\section{red. \\ Interenational Breain Researcch Sclhool}

Cellular Neuroscience and Oxidative Stress Society

C.

25 June - 1 July 2018 - Isparta / TURKEY

2018.brs.org.tre

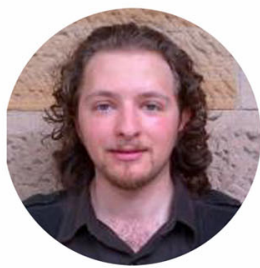

Dr. Nady BRAIDY (Australia)

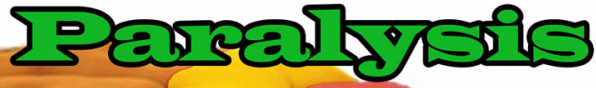

intanterners
Dr. Sergio PAREDES

(Spain)

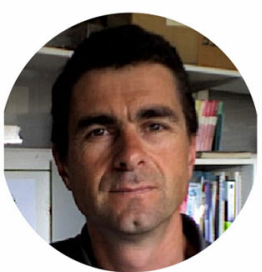

Dr. Denis ROUSSEAU (France)

Patch Clamp \& Calcium Signaling
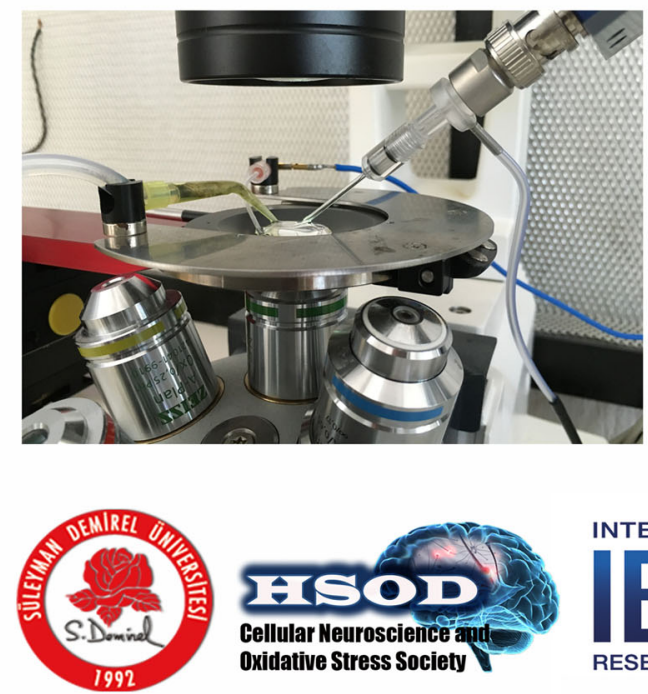

INTERNATIONAL BRAIN

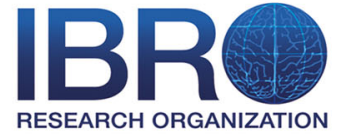

Cell

Culture

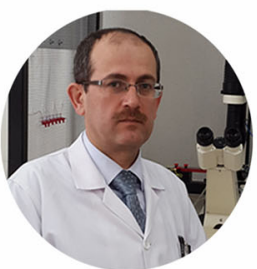

Dr. Mustafa NAZIROĞLU

(Turkey)
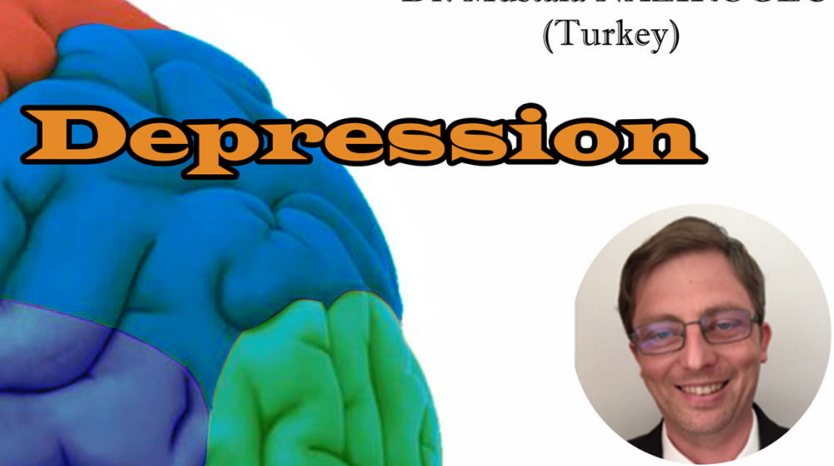

Dr. László PECZE (Switzerland)

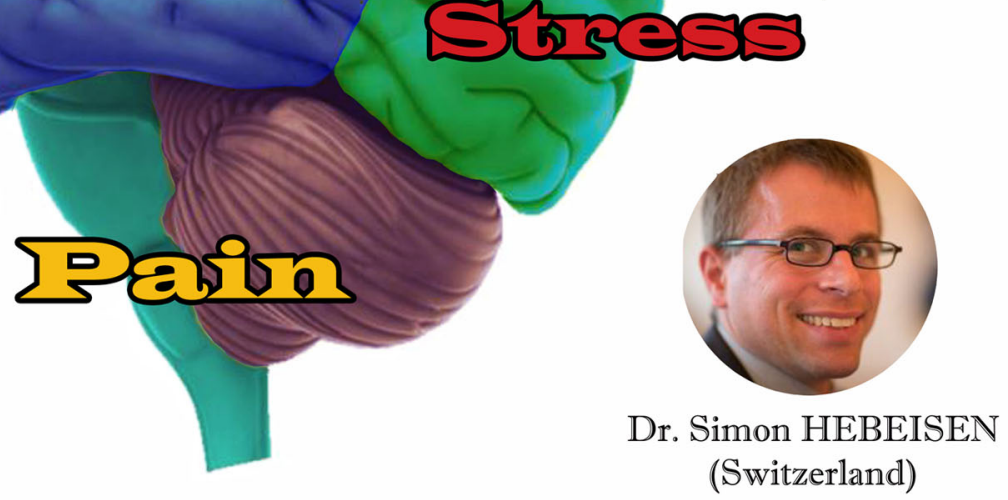

Dr. Simon HEBEISEN (Switzerland)
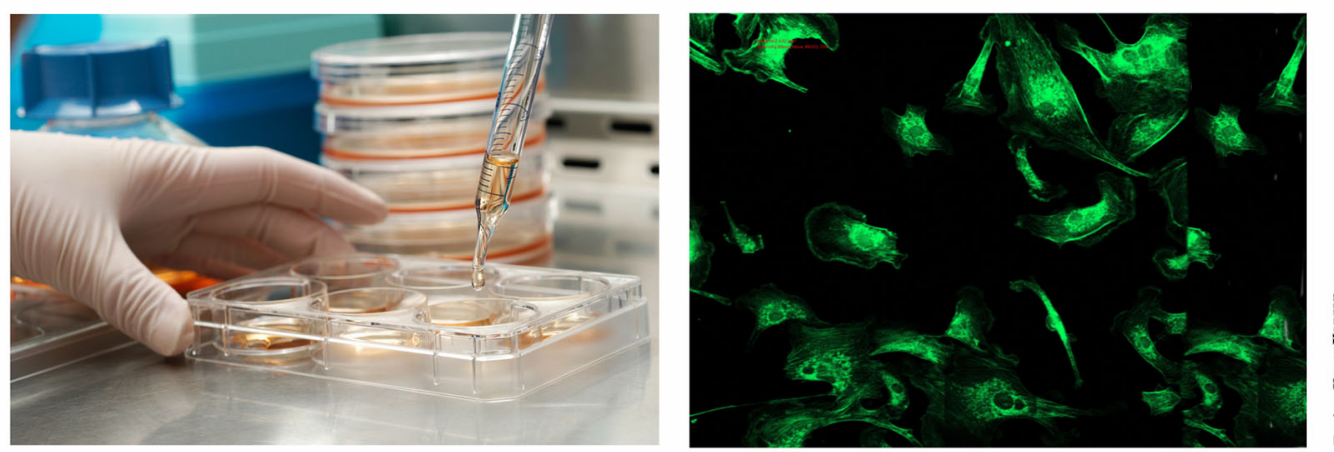

Yestern Blot \& Confocal IMicroscope

Contact:

Neuroscience Research Center, Suleyman Demirel University, Faculty of Medicine, Isparta / TURKEY Tel: $\quad+902462113641$ e-mail; norobam@sdu.edu.tr

arta 
Date: Contributor Name:

Contributor Address:

Manuscript Number (if Know):

Re: Manuscript entitled.

For publication in Journal of Cellular Neuroscience and Oxidative Stress (JCNOS) published by Cellular Neuroscience and Oxidative Stress Society (http://hsord.org.tr/), Isparta, Turkey.

Submission of a manuscript implies:

- that the work described has not been published before (except in the form of an abstract or as part of a published lecture, review or thesis);

- that it is not under consideration for publication elsewhere;

- that its publication has been approved by all co-authors, if any, as well as by the responsible authorities at the institute where the work has been carried out;

- that, if and when the manuscript is accepted for publication, the authors agree to automatic transfer of the copyright to this publisher;

- that the manuscript and figures will not be published elsewhere in any language without the consent of the copyright holders;

- that written permission of the copyright holder is obtained by the authors for material used from other copyrighted sources, and that any costs associated with obtaining this permission are the authors' responsibility.

Copyright notice: The contributor and the company/employer agree that all copies the final published version of the contribution or any part thereof distributed or posted by them in print or electronic format as permitted herein will include the notice of copyright as stipulated in the journal and a full citation to the journal as published by Cell Membranes and Free radical Society, Isparta, Turkey.

\section{CHECK ONE BOX}

( ) Contributor owned work:

Contributor's Print name and title...

Contributor's signature.

.Date:

Co- Contributor's Print name and title

Contributor's signature.

Date:

Co- Contributor's Print name and title

Contributor's signature.

Date:

Co- Contributor's Print name and title

Contributor's signature.

..Date:

Co- Contributor's Print name and title.

Contributor's signature.

Date:

( ) Company-Institution owned work:

Company-Institution (Employer for here).

Date:

Authorized signature.

..Date: 


\section{Journal of Cellular Neuroscience and Oxidative Stress}

\section{Principal Contact}

Prof. Dr. Mustafa NAZIROGLU / Editor in Chief

Suleyman Demirel University, Faculty of Medicine, Department of Biophysics 32260 Cunur - Isparta / TURKEY

Phone: +902462113641 Fax: +902462371165

mustafanaziroglu@sdu.edu.tr

biophysics@sdu.edu.tr 